\title{
Government Ethical Problems: Political Neutrality of Bureaucracy in Local Election
}

\author{
Teguh Yuwono. \\ Department of Politics and Government Science \\ Universitas Diponegoro \\ Semarang, Indonesia \\ teguhyuwonos@gmail.com
}

\begin{abstract}
There are several interesting research results found. Firstly, since incumbent head of regency (called Bupati) takes part in the local election, it is inevitable that bureaucracy is used by the incumbent Bupati to win the election; Secondly, bureaucracy is on the position that it can not refuse to the Bupati commands in related to the winning team of the incumbent candidates. Thirdly, there are strong evidences that bureaucrats also take advantage by getting involved in political struggle for power in the local election. The bureaucrats are hoping to be promoted because of supporting the Bupati in the prior local election process. Fourthly, there are many administration "abuse of powers" imposed by Bupati prior to the local election process. Finally, it is found that in practice there are no strong power to stop this Bupati ultimate power since the Bupati holds strong and highest political influence in the local level. Interestingly, among these research results, there is "mutual" political cooperation between the Bupati (as political person) and the bureaucrats (as administration person) in struggling for power. Several policy options are provided to solve the problem of politicking of bureaucracy.
\end{abstract}

Keywords - political neutrality, bureaucracy, dichotomy politics and administration, abuse of power.

\section{INTRODUCTION}

Debate on dichotomy between politics and bureaucracy has long been an interesting part in the study of politics and governance [1]. Public administration expert, such as Woodrow Wilson confirmed that bureaucracy should be neutral from politics. The main reason for this neutrality is that bureaucracy should serve all people, not steered by political motive so that it does not become professional as idealized by Max Weber. Bureaucracy should be prevented from cooptation by politics since bureaucracy should prioritize services to all people across political parties [2].

Whereas other experts, such as, James Svara has different opinion from Wilson. He confirmed that bureaucracy can not avoid politics. Bureaucracy is a part of political process, especially in policy making process. Exchanges of bureaucracy and political is avoidable, in a sense that they should interact each other to make a policy. If politics is defined as policy making, it is then not avoidable to separate politics and bureaucracy. It means that dichotomy between politics and bureaucracy is not relevant [3].

Meanwhile, in Indonesian context, particularly in the election aspect, a concern of bureaucratic neutrality from politics is a very hot issue. Government policy of Indonesia has clearly confirmed that bureaucracy should be neutral from politics. There is a strong ban for bureaucrats to engage in politics. The main reason for this is that bureaucracy may be used as political means to get their political objectives [4]. In sum, there is an ethical problem related the question of whether bureaucracy should be neutral from politics. The attention toward bureaucratic neutrality becomes a main issue in local elections both in Pemalang and Boyolali loal regencies. Pemalang and Boyolali are two regencies in Central Java Provinces that experience a problem of bureaucratic neutrality from politicking processes.

\section{RESEARCH METHOD}

Since this research is going to reveal a story behind the fight of neutrality between bureaucracy and politics, the research method occupies qualitative type which is best suitable to deeply discover processes or contexts behind the phenomena studied [5]. Qualitative type of research provides more insight and deeply understanding of meaning, process and contexts of phenomenon studied. People who are selected to be informants are candidates, bureaucrats, political party activists, the campaigning team members, a member of general election commission (KPU) and also election supervisory body (Bawaslu).

Observation is occupied to how bureaucrats and the candidates relates each other in terms of the local election and also how Bawaslu deal with bureaucracy neutrality issue. Finally FGD is occupied to ensure data triangulation gotten from cross answers 
to invited many informants to come ad discuss together in the forum to clarify many issues related to the questions of bureaucracy neutrality [6].

\section{RESULT FINDINGS AND DISCUSSION}

Although the debate of neutrality of bureaucracy from politics has been very long time, but the issue is always up to date. This is because existence of current bureaucracy engages with political in terms of the meaning of policy, conflict or power struggles [7]. This subject are of research in bureaucracy neutrality in politics is still important since the politicking processes of bureaucracy is still taking place. The main objective of this research is to explain neutrality of bureaucracy in the political life especially in the local election of Pemalang and Boyolali regencies, Central Java Province.

The debate of neutrality of bureaucracy from politics has been long interesting theoretical discussion [8]. Substantially the theoretical discussion of the bureaucracy neutrality is divided into two groups. First group is a group of experts who subscribe the idealism theoretical perspective that bureaucracy must be neutral from political intervention. In this expert group, the bureaucracy must be act professionally and serve people of the country equally without political motives. Experts who joined in this first groups are for example Woodrow Wilson, Frank Goodnow, or even Max Weber [9].

These experts interpret that the politicsbureaucracy dichotomy as a analytical construct used to express legislative supremacy as well as institutional ban on particularism [10]. According to Wilson, one can still use to draw a clear line against certain forms of politicians (such as elected members) involvement in bureaucratic hierarchy. The dichotomy should be supported as professional standard in politicalbureaucracy/manager government [11].

The second group is a group of experts who have theoretical of thinking that bureaucracy in practice may not be able to avoid politics [12]. The bureaucrats live in a situation where politics is always a part of their roles. This group of expert is often mentioned as a group of realistic view of perspective. Experts who joined in this second groups are for example James Svara, Anderson, Agranoff and Sir Paul Hasluck. Hasluck strongly confirmed that "the public service can not avoid politics anymore than fish can avoid the water in which they swim.

They confirmed that almost throughout the history of the politics-bureaucracy/administration divisions, bureaucrats have played an important active role in policy process. Intergovernmental management inevitably involves public bureaucrats in political activities. They are not only policy advisers but also politically expert pressure for adoption of their proposal [13]. The dichotomy of politics and bureaucracy is initially focused for professional standard in council-manager government, not as actual behavior of a bureaucrats.

Interesting point from these western theoretical debate on politics-bureaucracy dichotomy is clear that bureaucracy may engage in politics in terms of policy making process. The bureaucrats should play active role in political process (such as lobbying or so forth) in order to make sure that their policy proposal may be approved by political institution body. Moreover, the bureaucracy should be neutral from politics in the context of struggle for power. It means that the bureaucracy should be professional and nonpartisan.

Research results show that there are several important findings in regard to the main research questions. Firstly, since incumbent head of regency (called Bupati) takes part in the local election, it is inevitable that bureaucracy is used by the incumbent Bupati to win the election. Bupati uses informal method of power to influence the bureaucrats. Since the local bureaucrats were formally appointed by the bupati, there is no opportunities for the bureaucrats to avoid this strong influences of bupati. Interviews with civil society activists in Pemalang and Boyolali confirmed that the bureaucrats were working under pressure since timely closer to local election day, they are forced to serve political mission of the bupati incumbent candidate.

A high rank bureaucrat in Boyolali said that the local election in Boyolali is full of politicking. The bureaucrat must be loyal to the Bupati and follow what the bupati and his team's commands. the bureaucrats were used as political instrument of the bupati winning team to influence their people or supporters. Sanctions were always used to pressure and make the bureaucrats to be loyal to the bupati. The bureaucratic system was not a conducive situation to work prior to the election day. A lower rank of the bureaucrats in Pemalang confirmed that the top bureaucracy ranks tended to select their activities which were considered having benefits to the incumbent candidate. These bureaucratic activities were selected based on the number of people come. The more people come, the more priority of the bureaucrats to attend the event. It means that the bureaucrats tended to attend to the outdoor activities where the number of people to come was high.

Secondly, bureaucracy is on the position that it can not refuse to the Bupati commands in related to the 
winning team of the incumbent candidates. The position of bupati to sign formally for the bureaucrats' promotion and position placement, make it influence the politics of bureaucracy strongly. Interviews with several high rank bureaucrats in Pemalang and Boyolali revealed that they were in the position not to be able to avoid the bupati powerful role, since replacement and degradation was used to threat the bureaucrats. In the case of Boyolali, there was a bureaucrats that replaced in the remote area office (sub-district) due to refuse the bupati command to be loyal to the ruling political party.

In this context, the position of bureaucracy is then powerless since the political intervention of the bupati is very strong. A bureaucrat who is not ready to respond to this political pressure, he/she then tends to follow the bupati political mission in winning the local election. The bureaucrats are used to serve political motifs of the incumbent candidate.

This threat to bureaucrats is echoed no only by the incumbent candidate, but also by older brother of the incumbent candidate in Boyoali regency. This older brother of the incumbent candidate is a strong man who arrange almost all political aspects in Boyolali including dictates the incumbent candidate in making any policies related to political things. Political pressures to the bureaucrats in Boyolali very strong both formally and informally. The bureaucrats are mobilized to politically support to the incumbent candidate by actively come and participate in the political meeting of the winning team of the incumbent candidate. Interview with a member of Bawaslu confirmed that this candidate behaviors and his winning team are very open and almost everybody in Boyolali bureauracy know it. Bawaslu and KPU seems powerless to tackle this neutrality issue of the bureaucracy in the local election processes.

Thirdly, there are strong evidences that bureaucrats also take advantages by getting involved in political struggle for power in the local election. The bureaucrats are hoping to be promoted because of supporting the Bupati in the prior local election process. This is similar to mutual political cooperation that the both sides have positive effects from this position.

A member of Bawaslu in Pemalang and Boyolali agreed to say that a structural bureaucrat is also looking for an opportunity to promote their position by an instant way, namely loyal or serve all supporting needs of the incumbent. The incumbent candidate needs people vote to win the election, and the bureaucrats may be able to supply this need to the candidate. This is just like a supply-demand concept in political economy. This relational political collusion between the incumbent candidate and the bureaucrats is taking place as a response to political market needs.

This type of political collusion is really dangerous and has a potential problem. In the sense that if the incumbent candidate supported by the bureaucrats do not win the election, the future of the bureaucrats' career is in danger as well. The new bupati may be able not to promote or to support the bureaucrats who do not support him in the prior local election. This partisan politics of the bureaucracy may lead to the negative impacts of public services. Energies of bureaucracy used for political struggle will influence the professionalism of the bureaucracy to serve the people.

Fourthly, there are many maladministration ("abuse of powers") imposed by Bupati prior to the local election process. The incumbent bupati who is going to run for the next term competition in the local election has already for sure prepare to arrange anything in order to win an election. He or she prepares everything prior to the election day. This preparation is relating to strategically arrange the bureaucrats' position in which the bupati gets political advantages from them. The easiest way of the incumbent to prepare for this political competition is by promoting the bureaucracy cronies to fill the strategic position in the bureaucracy.

The incumbent bupati prepares this political step is not an instant way. His planning to run the candidacy is well prepared and uses the political party to get this political objective. The incumbent bupati has main agenda to win the next local election so that the processes of bureaucratic recruitment, promotion and development of the structural bureaucrat are in the powerful hand of the bupati. A member of Bawaslu in Boyolali mentioned that the incumbent bupati has strong self agenda to win election from very early time. The incumbent bupati has main political indicator in placing and promoting his bureaucratic staff, namely political loyalty. Loyalty is used to evaluate the staff promotion by the incumbent bupati. If the staff has closer relationships to the bupati, they will have more opportunities to have power that are placed as strategic position in the bureaucracy.

Finally, it is found that in practice there are no strong power to stop this Bupati ultimate power since the Bupati holds strong and highest political influence in the local level. Interestingly, among these research results, there is "mutual" political cooperation between the Bupati (as political person) and the bureaucrats (as administration person) in struggling for power. Pemalang case of local secretary who is not neutral in the local election is an evidence of the difficulty of 
political neutrality when the incumbent candidate is running for the competition.

The power of bureaucracy to avoid politicking pressure by the incumbent bupati is low. The bureaucracy is very much influenced by the incumbent candidate since the process of recruitment, promotion, development and termination of a bureaucrat are on the incumbent bupati hands. As a result, the bureaucrats tend to take a loyal action or choices rather than explicitly reject the incumbent bupati's political roles and power. The bureaucrats would then see "cooperation" or "mutual collaboration between the incumbent bupati and the bureaucrats are seen as a better way to the future of the bureaucracy.

Interview with an political expert from Universitas Sebelas Maret (UNS) confirmed that in the context of Boyolali political system, this is called as bureaucratic nepotism between the incumbent bupati (including his group) and the bureaucracy local government bodies. The two sides enjoys this unacceptable "mutual collaboration" and the people are then becoming the victim of the bureaucratic politicking by the incumbent bupati candidate. A tendency to politically influence the bureaucracy where the incumbent bupati who run for the local election competition is more openly happened than no incumbent. The bureaucracy is in danger if the incumbent bupati takes a part in an election candidacy.

\section{CONCLUSION}

Related to the main research questions of this paper, it is concluded that politicking of bureaucracy is still taking place in Pemalang and Boyolali since the bupati incumbent candidate take a part in the local election. The participation of the incumbent candidate in the local election make it impossible for the bureaucracy to free from the political election. The bureaucracy can avoid politicking and political motivation of the incumbent candidate since the replacement or promotion of the bureaucracy from lower to highest ranks of the bureaucrats is on the incumbent candidate's hands.

The bureaucracy both in Pemalang and Boyolali, particularly a bureaucrat who is in rank structural position, has difficulty to avoid politicking efforts by the incumbent candidate. Reasons for replacement and no promotion are used as a method to press the bureaucracy directly or indirectly. The incumbent candidate tends to politicize the bureaucracy to serve the political motivation, namely winning the local election. The incumbent candidate and its team seems not considering political ethics in winning the local election.
The relations between politics and bureaucracy in Pemalang and Boyolali regencies are very dynamical in the context of local election. This dynamic is important because it also brings to the question of long debate ethical problems between politics and administration. In practice, the hope of political neutrality of bureaucracy in politics is difficult to be guaranteed. The bureaucracy is in danger and difficult to avoid politicking if the incumbent candidate participates in a local election.

Several policy options are strongly urged to solve the problems of politicking of bureaucracy, as follows: Strong regulation needed to ensure that the bureaucracy must be neutral from political motivation of the candidate. The regulation should be provided to balance the role of bureaucracy in political context. Law enforcement and strong sanctions are needed in order to guarantee the importance of fair justice and competition in the local election particularly to prevent the incumbent candidate and the bureaucrats commit political collusion in winning the election. There should be a brave decision in regulation that if the candidate (either incumbent or not) uses bureaucracy as political machine to win the election, they must be disqualified from candidacy. Social control and participation from society is strongly required to protect the bureaucracy from unfair system of election political competition, particularly when the candidate can strongly influence the neutrality of bureaucracy.

\section{REFERENCES}

[1] Chhotray, V. \& Stoker, G. 2009. Governance Theory and Pratice: A Cross-Disciplinary Approach. Hampshire UK:Palgrave

[2] Chibba, M. 2009. Governance and Development: The Current Role of Theory, Policy and Practice. World Economics. Vol. 10, No 2 April-June. Hlmn. 79-108.

[3] Grindle, M.S. 2010. Good Governance: The Inflation of an Idea. Massachusetts: Harvard Kennedy School.

[4] Hadiz, V.R. 2012, "Decentralization and Democracy in Indonesia: A Critique of NeoInstitutionalist Perspectives". Development and Change 35: 697-718.

[5] Denzin, N.K. and Lincoln, Y.S. 2003. Collecting and Interpreting Qualitative Materials. Second Edition. London:Sage Publications.

[6] Henn, M., Weistein, M. \& Foard, N. 2006. A Short Introduction to Social Research. London: SAGE Pulications.

[7] Serrat, O. 2012. Innovation in the Public Sector. Asian Development Bank. Manila.

[8] Wagener, H.J. 2004. "Good Governance, Welfare and Transformation". The European Journal of 
Comparative Economics. Vol. 1. No. 1, hlmn. 127143.

[9] Skok, J.E. 1995. "Policy Issue Network and The Public Policy Cycle: A Structural Functional Framework for Public Administration, Public Administration Review, Vol. 55 No. 4, pp. 325-332.

[10] Kaufmann, D., A. Kraay, P. Zoido-Labato. 1999. Governance Matters. World Bank Policy Research Paper 2196.

[11] Montjoy, R.S. \& Watson, D.J. 1995. “A Care for Reinterpreted Dichotomy Standard in CouncilManager Governemnt", Public Administration Review, Vol. 55, No. 3, pp 231-239.

[12] Pierre, J and Peters, G. 2000, Governance, Politics and State, Houndsmills, UK:Macmillan.

[13] Svara, J. H., 1998. "The Politics-Administration Dichotomy Model As Aberration", Public Administration Review, Vol. 30, No. 6, pp. 52-59. 